\title{
EL ONGANIATO Y EL SUEÑO DE LA CASA PROPRIA: LA PROPAGANDA GUBERNAMENTAL DE LOS NÚCLEOS HABITACIONALES TRANSITORIOS (1966-1973)
}

ONGANIATO AND THE DREAM OF OWNING A HOUSE: GOVERNMENT PROPAGANDA OF THE TRANSITIONAL HOUSING SYSTEM (1966-1973)

Gabriela Gomes

Universidad Nacional de General Sarmiento gabrieladaianagomes@gmail.com

\section{Resumen}

En este trabajo nos interesa dar cuenta del rol que jugaron los Núcleos Habitacionales Transitorios en la dictadura autodenominada "Revolución Argentina" (1966-1973). Consideramos que el régimen los utilizó como un recurso propagandístico que apuntó a mostrar su "vocación social" por los más humildes. Asimismo, se convirtieron en un instrumento destinado a normalizar los espacios cotidianos de los sectores populares, inculcando nuevas y "modernas" formas de comportamiento y modos de habitar.

\section{Palabras claves}

Argentina. Dictadura. Núcleos Habitacionales Transitorios.

\section{Abstract}

In this paper analyzes the role played by The Transitional Housing System in the self called "Argentina's Revolution" (1966-1973). We consider that regime used them as a goverment propaganda that aimed to show it how his "social vocation" for the poorest. They became them as an instrument to normalize everyday spaces of the popular sectors, inculcating new and "modern" behaviors and ways of living.

\section{Keywords}

Argentina. Dictatorship. The Transitional Housing System. 


\section{Introducción}

El golpe de Estado del 27 de junio de 1966 autodenominado "Revolución Argentina" (1966-1973) que lideró Juan Carlos Onganía y derrocó al gobierno radical de Arturo Illia (1963-1966), emprendió un proyecto de modernización urbana por vía autoritaria. Allí los asentamientos informales fueron percibidos como una "anormalidad" en expansión, estigma del "subdesarrollo" y potencial "amenaza" para la paz social y la Seguridad Nacional. Siguiendo los patrones de la arquitectura moderna, los militares pusieron en marcha la erradicación de dichos asentamientos y a la vez se abocaron a la producción masiva de vivienda mediante la construcción de los conjuntos habitacionales de alta densidad. Se caracterizaron por su gran dimensión, el uso de grandes áreas urbanas sin fraccionamiento y su alto costo. Este tipo particular de agrupamiento de viviendas típico de los años 1960 y 1970 se dio en el contexto del arduo debate sobre la ciudad, el habitar moderno y los conjuntos como modelos de ciudad posible (BALLENT, 2004).

Una serie de estudios de los años setenta sostuvo que los asentamientos informales y el "subdesarrollo" metropolitano en Argentina obedecían a condiciones estructurales del capitalismo dependiente (CASTELLS, 1974; SCHTEINGART Y BROIDE, 1974; SEGRE, 1977). En el decenio de 1980 surgen los primeros estudios sobre la problemática habitacional abordada desde la perspectiva de la historia social urbana que privilegió el enfoque de los actores subalternos. Se interesaron por los problemas de hacinamiento, la promiscuidad, la falta de higiene, los abultados alquileres, las tramas de sociabilidad y los principales focos de conflictividad social de los sectores populares urbanos, así como sus estrategias de vida y habitacionales para acceder a mejores tipos de vivienda. Asimismo, abordan los múltiples mecanismos organizativos de producción del hábitat popular en su lucha por el acceso a la tierra frente a los intentos de ser erradicados (ALMADA ET AL., 1984; BELLARDI Y DE PAULA, 1986; TORRADO, 1982). Una de esas estrategias desplegadas para acceder a mejores tipos de viviendas fue la creación de las cooperativas de autoconstrucción y ayuda mutua como solución colectiva al problema habitacional. Asimismo, una parte significativa de los habitantes de la Ciudad de Buenos Aires encontró en el sub-mercado de alquiler de hoteles y pensiones una "salida" para mejorar sus condiciones de vida (AGOSTINIS ET AL,. 1995; CRAVINO, 2009; GAZZOLI, 2007).

Los estudios que abordaron el problema habitacional durante la "Revolución Argentina" ponderaron la relación entre el Estado y movimientos urbanos marginales, las múltiples formas organizativas de los sectores populares urbanos y las estrategias de intervención estatal a partir de las políticas de vivienda (DÁVALOS ET AL., 1987; TENTI FANFANI, 1989; ZICCARDI, 
1977; 1984). Buena parte de los trabajos se concentraron en las políticas de erradicación de las villas de emergencia en la Ciudad de Buenos Aires, que tuvieron continuidad durante el tercer gobierno peronista y la última dictadura militar (1976-1983) con variaciones de escala y despliegue del aparato represivo estatal. De acuerdo al proyecto de profilaxis social urbana promovido principalmente por los gobiernos militares, las políticas estatales se sustentaron en ciertos parámetros estéticos y morales que indicaban que se trataba de un sector social "peligroso" que debía ser erradicado (GOMES, 2016). De ese modo, se apostó a la construcción de complejos habitacionales para reubicar a los sectores marginales y buscar su "readaptación social" (ÁLVAREZ DE CELIS, 2005; BALLENT Y LIERNUR, 2014; DE LA TORRE, 2008; YUJNOVSKY, 1984). Como bien sostuvo Auyero y Hobert (2007: 232-233) la asociación entre villas miseria con "zonas de crimen", "amenaza" y "obstáculo" para el "progreso" se extiende desde 1956 hasta la década de 1970. Dichas ideas fueron difundidas por políticos y militares antiperonistas que veían en el incremento de las villas el retrato del "fracaso" de las políticas del "populismo" peronista. Asimismo, los informes periodísticos que se difundían en los medios de prensa masiva, referían al "temor" que generaban las villas y sus habitantes. En ese clima de ideas, su erradicación ganó apoyo de amplios sectores sociales.

Otro conjunto de investigaciones centró su atención en los intereses económicos vinculados a la vivienda como la industria de la construcción y el sector inmobiliario (CRAVINO, 2009; YUJNOVSKY, 1984). Por ejemplo, Yujnovsky (1984) analizó el problema habitacional centrado en las políticas estatales en Buenos Aires entre 1955 y 1983. Otra serie de trabajos enfatizaron en las formas organizativas de los sectores populares y entendieron al Estado como el principal opositor a ese movimiento social (BELLARDI Y DE PAULA, 1986; ZICCARDI, 1980). Las formas asociativas fueron parte de las estrategias de supervivencia de los sectores populares tal como lo demostraron Grillo, Lacarreu y Raggio para los de Buenos Aires (GRILLO ET AL., 1995). Por su parte, Barrios (2012) estudió un proyecto emblemático de autoconstrucción y participación directa conocido como el Plan Piloto de Realojamiento de Villa 7 que promovió la Comisión Municipal de la Vivienda bajo el gobierno militar de Alejandro Lanusse (1971-1973).

Asimismo, entre los estudios que privilegiaron la escala local, recientemente Rosa Aboy (2017) publicó en esta revista un dossier donde Massidda (2017) ofrece un análisis en perspectiva histórica sobre las disputas y negociaciones por el espacio urbano y las distintas estrategias de los sector populares por la apropiación del espacio en tres villas de la Ciudad de Buenos Aires entre 1958 y 1971: Castañares, Cildáñez (Villa 6) y La Lonja (Villa 5), las dos últimas fueron erradicadas en el marco del Plan de Erradicación de Villas de Emergencias y 
Barrios (PEVE) entre 1969 y 1971. En el mismo dossier Alvarez (2017) abordó la recepción del Movimiento Villero Peronista de la Capital Federal frente a la política de erradicación bajo el Plan Alborada del tercer gobierno peronista. Por su parte, García (2015) analizó el proceso de erradicación de villas miseria en Puerta de Hierro correspondiente al partido de La Matanza del Gran Buenos Aires entre 1966 y 2013.

Como se observa, buena parte de la bibliografía dedicada al período se concentró en la dimensión represiva de la dictadura que implicó el plan de erradicación de las villas miseria en la Ciudad de Buenos Aires y el conurbano. En ese sentido, consideramos que las investigaciones sobre vivienda social en las dictaduras militares de Argentina continúan como un campo abierto a nuevas indagaciones. Este trabajo se inscribe en la línea de estudios que inició Carme Molinero (2005) sobre la política social y la propaganda en el régimen franquista. Allí la autora muestra cómo más allá de los altos niveles y métodos represivos, el régimen desplegó un programa social y dispositivos propagandísticos para intentar captar a las masas, una estrategia que heredó de los falangistas pero que el franquismo supo explotar y potenciar. Asimismo, este trabajo dialoga con los aportes de Scheneider (2017) quien analiza la relación entre la propaganda oficial de la dictadura brasilera y su influencia en la vida cotidiana de los ciudadanos brasileros. Como se sabe las dictaduras militares carecen de legitimidad de origen, en este trabajo nos interesa analizar los usos propagandísticos que la "Revolución Argentina" hizo de los Núcleos Habitacionales Transitorios (NHT) como una estrategia de la programática revolucionaria que apuntó a la búsqueda de legitimidad social. Se trató de un tipo de vivienda provisoria, muy precaria, de tamaño reducido y con una estructura desmontable. Sin embargo, el régimen hizo de los NHT y del Programa de Erradicación de Villas de Emergencia un recurso propagandístico mediante el cual apuntó a mostrar su vocación social por los más humildes. Es poco lo que podemos decir acerca del impacto de ese tipo de propagandas así como su recepción en parte los sectores populares urbanos. De todos modos, consideramos que el análisis de las ideas allí contenidas y la forma en que fueron presentadas, nos brinda algunas pistas para comprender cómo se auto-representaba el régimen.

Nuestra hipótesis es que los NHT fueron un instrumento del gobierno militar destinado a normalizar los espacios cotidianos de los sectores populares urbanos, ya que se apuntó a inculcar nuevos valores morales, formas modernas de comportamiento y nuevos y "modernos" modos de habitar. El principal objetivo que perseguía la promoción de ese tipo de vivienda absolutamente precaria era la transformación radical de los espacios cotidianos de los beneficiarios. Eso formó parte de un objetivo mayor que persiguió la dictadura: reeducar y resocializar a los sectores populares a través de distintas políticas promovidas desde la 
Secretaría de Promoción y Asistencia a la Comunidad (SEPAC) y la Secretaría de Estado de Vivienda (SV), ambas dependientes del Ministerio de Bienestar Social creado por Onganía en 1966 (GOMES, 2016a). Este trabajo se divide en tres secciones. En la primera se realiza un breve recorrido histórico sobre los intentos de solucionar el problema de los asentamientos informales en el período previo a la dictadura de 1966. Luego se aborda la promoción social y cooperativismo como base programática del proyecto social del Onganiato. Finalmente, se analizan algunos de los recursos propagandísticos sobre la erradicación de villas miseria que utilizó el régimen al calor de la movilización social que confluyó en el Cordobazo de mayo de 1969. ${ }^{1}$

\section{Antecedentes de la alternativa "modernizadora" al problema de la vivienda: autoconstrucción y erradicación}

A partir de los años cincuenta el proceso latinoamericano de urbanización se aceleró y profundizó la crisis habitacional. El crecimiento de la pobreza y la falta de infraestructura urbana eran vistos como síntoma de "atraso". Bajo el paradigma "modernizador", los organismos internacionales como la Organización de Naciones Unidas (ONU), la Organización de Estados Americanos (OEA) y el Banco Interamericano de Desarrollo (BID), consideraron la transformación del hábitat como un dispositivo de modernización social. De ese modo, en el Tercer Mundo se difundieron conceptos como ayuda mutua, esfuerzo propio y autoconstrucción junto al rol supletorio del Estado en materia social, que apelaba a la participación de los sectores marginados en la ejecución de obras y servicios. La preocupación por el desarrollo urbano formó parte de la agenda de casi todos los países y fue compartida por los científicos sociales y técnicos especializados en la problemática urbana. Así comenzaron a circular los primeros planes de erradicación de villas y los de Autoconstrucción Asistida en América Latina, Asia y África. En Argentina, uno de los primeros proyectos de este tipo lo llevó a cabo la entidad Emaús en 1956 con los pobladores de la Villa Tabaré (No 16). ${ }^{2}$ Estrechamente vinculada directamente a su sede francesa, Emaús financió proyectos similares en otros países. Asimismo, el Programa del Instituto de la Vivienda de la Provincia de Buenos Aires, fue el primer organismo estatal que inició y financió planes de vivienda de Autoconstrucción Asistida,

\footnotetext{
${ }^{1}$ Agradezco los comentarios de la Dra. Rosa Aboy a una versión preliminar de este trabajo y a los evaluadores del presente artículo por sus comentarios y sugerencias.

2 Emaús fue creada en la segunda posguerra por el francés sacerdote católico Henri Grouès, conocido como Abbé Pierre -miembro de la Resistencia-. Surgió como un movimiento destinado a brindar ayuda a las familias que fueron desbastadas por la guerra (LA NACIÓN, 2007). Sitio web disponible en: http://emausbuenosaires.com.
} 
utilizando exclusivamente la mano de obra de los participantes. El programa se extendió entre 1959-1973 y tuvo como resultado la construcción de 2.687 viviendas en 43 localidades de la provincia (BELLARDI \& DE PAULA, 1986:87-88).

Siguiendo el discurso "modernizador" de los tecnócratas desarrollistas, en 1956 se creó la Comisión Nacional de la Vivienda que elaboró el primer Plan de Erradicación de Villas y promovía la construcción de viviendas subsidiadas por el Estado. El gobierno de Arturo Frondizi también contó con un plan similar, dependiente del Ministerio de Obras Públicas. Por su parte, en 1958 el Partido Comunista impulsó la creación de la Federación de Barrios y Villas de Emergencia de la Capital Federal -entidad vinculada a Unión de Mujeres Argentinas-, que se constituyó como interlocutor válido entre organizaciones de las distintas villas y el gobierno municipal de la Capital Federal, logrando contactos con el Concejo Deliberante. Posteriormente, en el gobierno de Arturo Illia se sancionó la Ley No 16.601 (1964) que dio lugar al Plan Piloto de Erradicación de Villas de Emergencias No 5, 6 y 18 del Parque Almirante Browm, reglamentado por la ordenanza municipal $N^{\circ} 20.220$ dictada en junio de 1965 . Allí se contempló la construcción de viviendas destinadas a las poblaciones de las Villas y la formación de Centros Comunitarios en cada núcleo villero, encargados de generar condiciones de apoyo y credibilidad por parte de sus pobladores para posibilitar su erradicación. El Plan apuntaba a que dichos Centros operasen como disparadores del cambio en la mentalidad en los pobladores, para que abandonaran su actitud "estática" y participaran dinámicamente. Asimismo, se encargarían de tres tipos de tareas: 1) sociales: elaboración de censos, promoción de obras de infraestructura e equipamiento colectivo, organización de actividades culturales y deportivas; 2) médicas: llevar adelante las campañas de vacunación y atención sanitaria; 3) educativa: promover campañas de alfabetización y de seguimiento escolar. Para los individuos que se opusieran a la erradicación y garantizar su desalojo inmediato, se estableció en la legislación vigente, la categoría jurídica de "intruso" que anulaba su derecho a solicitar recurso de amparo.

El Plan Piloto de 1964, a diferencia del Plan de Erradicación de Villas de Emergencia (PEVE) del Onganiato que veremos a continuación, contempló obras para mejorar las condiciones de habitabilidad en las villas. Se repararon algunas calles interiores de los barrios, se tendió redes de alumbrado público, se reconstruyeron viviendas y se promovieron campañas de vacunación (BELLARDI \& DE PAULA, 1986:14-15). En 1964 el movimiento villero se vinculó con la protesta gremial y acompañó el Plan de Lucha de la CGT (PRIVITELLIO \& ROMERO, 2005:27). Eso impidió que el gobierno radical avanzara con su plan de erradicación. Si bien, el poder ejecutivo reconoció como interlocutor a la Federación de Barrios y Villas de 
Emergencia, durante la aplicación del Plan Piloto de Erradicación, el gobierno municipal intentó disolverla y reemplazarla por organizaciones subordinadas al poder estatal.

\section{Las bases del proyecto social del Onganiato: promoción social y cooperativismo}

La problemática social ocupó un lugar preponderante en la programática fundacional del gobierno militar. La creación de más fuentes de empleo, educación, salud y la promoción humana fueron de vital interés. En parte el gobierno militar hizo propias una serie de preocupaciones sociales contenidas en la agenda de los organismos internacionales como el BID, la OEA y la ONU, que consideraron la transformación del hábitat como un poderoso instrumento de cambio social. En ese sentido, la falta de infraestructura urbana y vivienda se transformó en una de las prioridades del régimen, que a su vez le permitió ganarse el apoyo de los empresarios de la industria de la construcción. Por ejemplo, la OEA estimuló a los gobiernos para que destinaran terrenos fiscales al emprendimiento de proyectos de vivienda cooperativa y apostaran a la organización de cooperativas urbanas para solucionar los problemas de los estratos bajos, relacionados al déficit habitacional (MINISTERIO DE BIENESTAR SOCIAL, 1969:84-86). Entre sus objetivos programáticos se buscó "crear las condiciones para un creciente bienestar social de la población, desarrollando la seguridad social, elevando al máximo posible los niveles de salud y facilitando su acceso a una vivienda digna" (MINISTERIO DE BIENESTAR SOCIAL, 1968b: 107). ${ }^{3}$

En ese marco se creó el Ministerio de Bienestar Social con la Ley No 16.956 Orgánica de Ministerios Nacionales, que los redujo de 8 a 5 (Interior, Exterior, Economía y Defensa). De ese misterio dependieron las siguientes Secretarías de Estado: de Promoción y Asistencia a la Comunidad (SEPAC), de Seguridad Social (SESS), de Salud Pública (SESP) y de Vivienda (SV). El ministerio se ocupó de la formación de cuerpos técnicos y de promover la participación activa de la población en la gestión de lo social. Para cubrir los cargos gubernamentales se abocó a la búsqueda de técnicos y profesionales, donde la Ciudad Católica ${ }^{4}$ y el Ateneo de la República ${ }^{5}$ fueron los principales espacios de reclutamiento. Dichos técnicos se concentraron fundamentalmente en el área de educación, el Ministerio del Interior, el Ministerio de Bienestar

\footnotetext{
${ }^{3}$ El subrayado es nuestro.

${ }^{4}$ La Ciudad Católica fue una organización anticomunista, antiprogresista y antiliberal de origen francés, que rechazaba la organización político-partidaria, la masonería y el laicismo (Cf. SCIRICA, 2010).

${ }^{5}$ El Ateneo de la República surgió en 1962 como un grupo cercano al catolicismo reaccionario, creado por Mario Amadeo y Máximo Etchecopar. Siguió una orientación antiliberal, anticomunista y reivindicó el orden corporativista y un nacionalismo de raíz hispanista-católico.
} 
Social y la SEPAC y desde esas carteras promovieron su proyecto comunitarista. Para citar un ejemplo, el ingeniero y empresario de la construcción Roberto Gorostiaga fue presidente de la Ciudad Católica y director de la revista Verbo (1959-1966) hasta que se hizo cargo de la SEPAC (1966-1967). En el área económica la influencia de dichos grupos fue menor, aunque hubo ateneístas vinculados a los equipos de economía (O'DONNELL, 2009: 95). Por ejemplo, el vicepresidente del Ateneo de la República, Pedro Eduardo Real (1966) fue presidente del Banco Central y Rafael García Mata ocupó la Secretaría de Estado de Agricultura y Ganadería (GOMES, 2016b).

La SEPAC se creó en octubre de 1966 y fue pensada como una institución que se abocaría a la promoción social de grupos sociales que habitaban en regiones postergadas. Eso se lograría a partir del trabajo conjunto con la comunidad y los organismos públicos y privados en las zonas rurales "subdesarrolladas" y en las villas de emergencia. Entre sus objetivos se destacó la creación de escuelas primarias y centros culturales, mejoras en el nivel sanitario, regulación del mercado de trabajo y de la distribución del ingreso y la construcción de viviendas dignas para "impedir" la formación de nuevas villas miseria. El bienestar social y la promoción comunitaria fueron los pilares fundamentales en los que descansó la programática "revolucionaria", que implicó la vigencia del principio de subsidiaridad del Estado y la responsabilidad del individuo en su autodesarrollo. En ese esquema los municipios adquirieron gran centralidad. En esos principios descansó la idea del desarrollo comunitario. La participación social y la autogestión fueron promovidas para mejorar el nivel de vida de los sectores sociales marginales.

Cabe señalar que ideas similares estuvieron presentes en el gobierno demócrata cristiano chileno, conocido como la "Revolución en Libertad" (1966-1970), liderada por Eduardo Frei Montalva. En su gobierno se creó el Programa de Promoción Popular, cuyo ideólogo fue el sociólogo jesuita Roger Vekemans. ${ }^{6}$ Desde ese programa se intentó organizar al mundo popular en Consejos de Vecinos, Centros de Madres (CEMA), Centros de Padres, Clubes Deportivos, Centros Culturales, Consejos Juveniles, Consejos Comunitarios, Cooperativas, etc. (FREI MONTALVA, 1964). Se entendía que los sectores marginales, históricamente excluidos, eran los protagonistas de la "Revolución en la Libertad" (VEKEMANS y VENEGAS, 1966). Las organizaciones comunitarias fueron concebidas como la base de la democracia social y como

\footnotetext{
${ }^{6}$ Roger Vekemans dirigió la Escuela de Sociología de la Universidad Católica y estaba vinculada al cardenal Raúl Silva Henríquez. Fundó el prestigioso Centro de Desarrollo Social de América Latina (DESAL) y actuó como asesor de la Acción Sindical Chilena y de la Unión Social de Empresarios Cristianos (USEC). En 1970 viajó a Colombia y se dedicó al estudio de la Teología de la Liberación (EL MERCURIO, 24 de octubre de 2007).
} 
un instrumento para neutralizar a la izquierda y reducir los conflictos sociales. En ese sentido, los líderes comunitarios tuvieron la tarea de organizar y movilizar las bases y envolverlas en la política estatal. Nos parece pertinente dicha aclaración porque algunas de las directrices de la propuesta comunitarista del Onganiato estuvieron inspiradas en el Programa diseñado por Vekemans. Por ejemplo, la Directiva de Participación de la Secretaría del Gobierno a cargo de Mario Díaz Colodrero, dependiente del Ministerio del Interior (GIORGI, 2014), fue diseñada por José Luis de Ímaz a pedido de Colodrero en abril de 1967 (PRIMERA PLANA, 1968). De acuerdo a su testimonio, la directiva se inspiró en la experiencia del desarrollo de la comunidad chilena. $^{7}$

El proceso de transformación social de la "Revolución Argentina" fue concebido de abajo hacia arriba: la participación debería iniciarse en las comunidades intermedias, mediante la socialización de los intereses individuales orientados hacia un interés mayor que era el bienestar de la nación.

cuando alentamos el concepto de la comunidad para fundar en ellas las bases de una auténtica democracia, cuando nos empeñamos en gobernar con eficacia, en elevar el nivel de vida de la población, en mejorar la vivienda, en el cuidado de la salud pública, en promover la cultura y la educación, estamos cumpliendo con nuestro plan político (ONGANÍA, 1967).

Por bienestar social se entendía el mejoramiento integral del individuo y su familia tanto en el plano de valores culturales y espirituales como en la satisfacción de sus necesidades intelectuales, el acceso a la salud, educación, vivienda digna y trabajo (GOMES, 2011 ; 2016a). Supuestamente, el proceso de "transformación social" implicaba la caducidad del divorcio pueblo-gobierno y terminar con la lógica del paternalismo estatal, el asistencialismo y la demagogia (MINISTERIO DE BIENESTAR SOCIAL, 1968a: 17). Sin embargo, mientras se trataba de "erradicar" un tipo particular de "paternalismo político", asociado al peronismo y otros partidos-, paralelamente se promovía el fortalecimiento de las entidades intermedias. Eso terminaba por reforzar una nueva forma de paternalismo estatal, donde un gobierno supuestamente "moderno" se convertía en el principal promotor del cambio de una sociedad que vivía en condiciones de "atraso".

\footnotetext{
7 De Ímaz ingresó al PDC argentino en 1964, motivado por el triunfo de Frei Montalva. Desde entonces, viajó varias veces a Santiago de Chile para conocer los proyectos de la Reforma Agraria y analizar el funcionamiento del Consejo Nacional de Promoción Popular. Allí, se puso en contacto con los líderes del PDC y estableció una relación particular con Jacques Chonchol, el ideólogo de la Reforma Agraria (DE ÍMAZ, 1977).
} 
La "Revolución Argentina" apuntó a consolidar los valores morales según la tradición occidental y cristiana. Para ello buscó preservar la integridad de la familia nuclear, a partir de la promoción de la vivienda y el deporte. Se consideró que el déficit habitacional era la principal causa de promiscuidad, lo que ponía en "peligro" al núcleo familiar. Asimismo, se promovieron instalaciones recreativas para el "sano" empleo del tiempo libre en familia. Para afrontar dicho problema, desde el Ministerio de Bienestar Social la "Revolución Argentina" alentó la auto-organización de la comunidad en cooperativas, mutualidades, Uniones Vecinales y Comisiones de Ayuda Mutua. Se pensó en un sistema de construcción de vivienda social que permitiera abaratar los costos y alentara la demanda mano de obra local, a partir de la conformación de entidades de ayuda mutua y sociedades mixtas de trabajadores y empresarios (MINISTERIO DE BIENESTAR SOCIAL, 1968c). La Dirección Nacional de Cooperativas dependiente de la SEPAC, se encargaría de su gestión, control y asistencia técnica. Las cooperativas fueron concebidas como instrumentos poderosos para organizar la iniciativa de los trabajadores y sectores medios y convertirlos en sujetos activos del proceso "revolucionario" (GOMES, 2016a: 92-94).

Un caso emblemático fue la construcción del Barrio Justo Suárez (1971-1975) propiciado por la Comisión Municipal de la Vivienda $(\mathrm{CMV})^{8}$ como resultado del Plan Piloto de Realojamiento de Villa 7, que consistió en construcción de 120 viviendas en altura (1 torre de 10 pisos y 5 bloques de 3 y 4 pisos). Fue producto de un programa experimental de realojamiento para la población de Villas de Emergencia en Mataderos, bajo un modelo de gestión participativa, que involucró a sus habitantes en el diseño e implementación del proyecto y aportaron su mano de obra a través de una capacitación previa (BARRIOS, 2012). Lo novedoso de dicha experiencia fue que las decisiones referidas a la calidad constructiva, concepción de la obra, distribución de los ambientes, forma de financiamiento, tamaño, tipo vivienda (individual o colectiva), fue resultado del trabajo conjunto entre los técnicos profesionales y el grupo participante (BELLARDI \& DE PAULA, 1986: 89-101).

Las inundaciones de octubre de 1967, producto del desborde de los ríos Matanza y Reconquista afectaron el sur y el oeste del Gran Buenos Aires (CLARÍN, 1967). En consecuencia, el gobierno decretó el estado de emergencia y puso en marcha un programa sanitario para evitar epidemias. El secretario de vivienda Estaban Guaia y el ministro de Bienestar Social Julio Álvarez impulsaron la Ley No 17.605 de Promoción Social, Construcción y Financiación de Viviendas, que dio lugar al Plan de Erradicación de Villas de Emergencia de la

\footnotetext{
${ }^{8}$ La CMV se creó en 1961 bajo la órbita de la Municipalidad de la Ciudad de Buenos Aires, se encargó de la promoción de vivienda social. En 1967 por Ley No 17.174 se estableció su funcionamiento autárquico y amplió su dominio legal hacia el Gran Buenos Aires.
} 
Capital Federal y del Gran Buenos Aires (PEVE). EI PEVE fue ejecutado por la Secretaría de Vivienda con el apoyo del Banco Hipotecario Nacional y el Comando de Ingenieros del Ejército, que asumió las tareas en la dirección técnica del Plan Nacional para la Construcción de Viviendas Transitorias. El artículo 7 de la Ley No 17.605, declaró que la "insalubridad" de una Villa de Emergencia era motivo suficiente para autorizar su erradicación. EI PEVE las definió como "agrupamientos de construcciones precarias y clandestinas destinadas a habitación, carentes de infraestructura, cuyos habitantes ocupan los terrenos en calidad de "intrusos", en situación de hacinamiento físico y en condiciones de deterioro social" (MINISTERIO DE BIENESTAR SOCIAL, 1968d: 54).

Inicialmente, se consideró que el PEVE contribuiría a erradicar el mercado informal, la especulación sobre la venta o alquiler de viviendas o cesión de derechos sobre tierras usurpadas. Allí se contempló el desalojo de 70.000 familias (20.000 en la Capital federal y 50.000 en los partidos bonaerenses circundantes), un total de 280.000 personas. Para los ideólogos del PEVE y los funcionarios del MBS, la erradicación permitiría ofrecer "mejores" condiciones habitacionales y "eliminar" la situación marginal producto de los "desajustes sociales". Supuestamente, se trataba de "auxiliar" a las familias que en razón de escasez de viviendas se habían visto forzadas a "invadir" terrenos ajenos y a desplazarse de sus lugares de origen en busca de mejores condiciones de vida (MINISTERIO DE BIENESTAR SOCIAL, 1968d: 8). Si bien no contemplaba su "eliminación arbitraria y violenta", lo cierto es que ante la resistencia de sus habitantes, el gobierno no escatimó en la represión.

La condición de "anormalidad" de las villas fue percibida como una potencial "amenaza" al orden social y a la vez un problema de Seguridad Nacional, que aún estaba a tiempo de erradicarse ya que sus habitantes estaban "dispuestos" a mejorar sus condiciones de vida (MINISTERIO DE BIENESTAR SOCIAL, 1968d: 26). Se estableció un orden de prioridades para la erradicación de las villas: 1) las afectadas por las inundaciones; 2) aquellas situadas en terrenos requeridos para las obras públicas y en los accesos a la Capital Federal; 3) aquellas cuyo grado de "motivación" para su erradicación resultara "satisfactorio"; 4) las que ocupaban terrenos aptos para la construcción de viviendas definitivas.

EI PEVE contempló una prueba piloto en la Capital Federal que se concretaría dos etapas. El primer programa correspondía a la vivienda transitoria que serviría como espacio de "adaptación" y garantizaría seguridad jurídica, física y sanitaria. Se consideró que los habitantes no estaban "capacitados" para vivir en departamentos por lo que serían trasladados a pequeños conjuntos habitacionales, llamados Núcleos Habitacionales Transitorios (NHT). Su construcción era precaria y desmontable y su objetivo era que los inconvenientes de su 
habitabilidad "despertaran" el deseo de los pobladores de "esforzarse" por obtener las viviendas definitivas, correspondientes al segundo programa (GUAIA, 1968). Como el gobierno militar pretendía desechar todo tipo paternalismo, consideró al esfuerzo personal como parte de la "solución" al problema habitacional (MINISTERIO DE BIENESTAR SOCIAL, 1968d: 32). Se suponía que los NHT contribuirían a "desactivar" potenciales conflictos sociales ya que "mejorarían" sus modos de habitar y normalizarían el estado cívico de los pobladores.

Como hemos mencionado, uno de los objetivos del gobierno militar era garantizar la protección de la estructura familiar. En tal sentido, los NHT suponían el otorgamiento de mayores posibilidades para la intimidad hogareña debido al aislamiento acústico, la disponibilidad de un lote privado y la separación de espacios específicos para las tareas domésticas como cocinar, lavar y dormir (GOMES, 2016a).

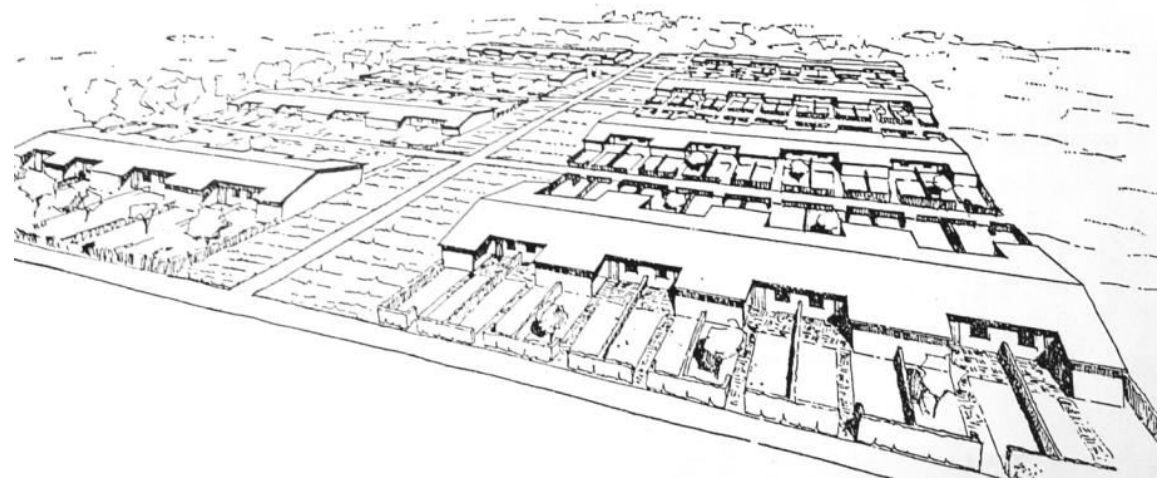

Figura 1- Plano de urbanización de las viviendas transitorias (manzana unidad). Fuente: MINISTERIO DE BIENESTAR SOCIAL, 1968d. 


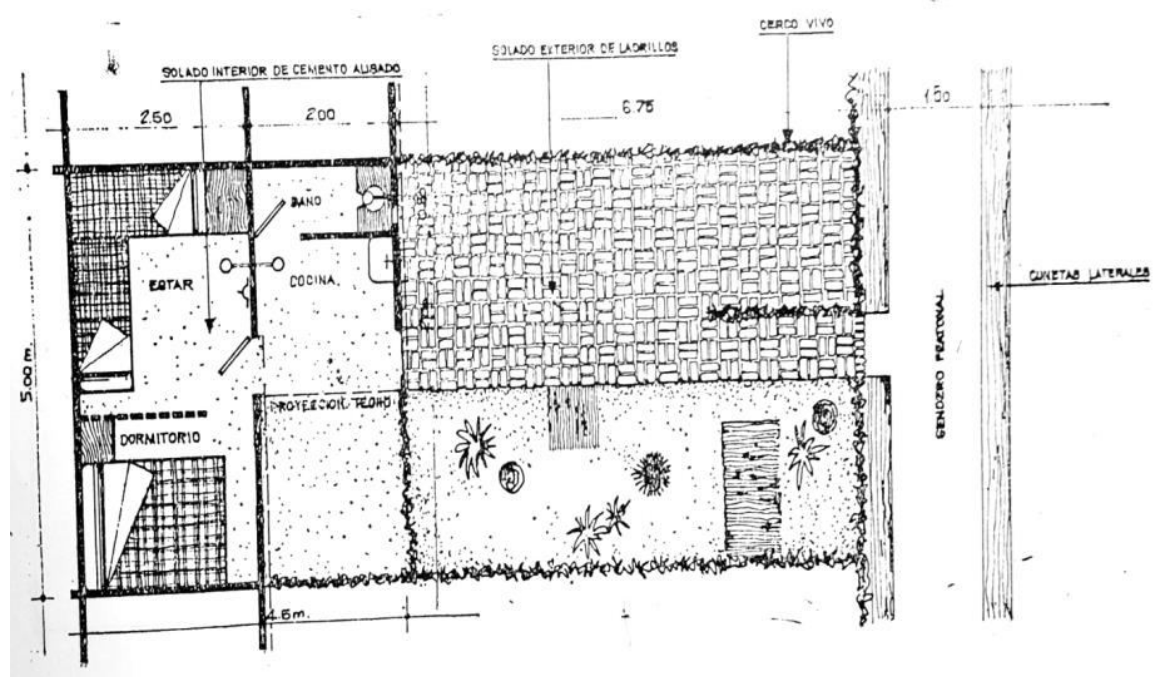

Figura 2- Diseño de vivienda transitoria

Fuente: MINISTERIO DE BIENESTAR SOCIAL, 1968d.

Como se observa en las figuras $\mathrm{N}^{\circ} 1$ y 2 , cada NHT fue pensado para una familia tipo, tenía una superficie cubierta de $22,5 \mathrm{~m}^{2}$ y $33.75 \mathrm{~m}^{2}$ de espacio verde, lo que sumaba un total de $56.25 \mathrm{~m}^{2}$. De los $10.000 \mathrm{~m}^{2}$ de cada manzana, $2.800 \mathrm{~m}^{2}$ correspondían a espacios comunes (sendas peatonales) y $7.200 \mathrm{~m}^{2}$ era la superficie destinada a la construcción de 128 viviendas. Pese a la estrechez de las viviendas, se le otorgó importancia al pequeño terreno individual y al jardín, ya que se recomendaba la construcción de huertas, pensadas para contribuir al sustento de la economía familiar. Se proyectaron un total de $15 \mathrm{NHT}$, de los cuales tres se construyeron en la zona sur de la Ciudad de Bs As -que alojaron un total de 849 familias provenientes de las Villas No 2, 5, 22, 25, 27,30 y 34 familias desalojadas por el ensanche de la Avenida 9 de Julio-, y el resto en el Conurbano (DE LA TORRE, 2008:161). En La Matanza, el gobierno de la Ciudad de Buenos Aires construyó 1.018 viviendas de este tipo, destinadas a familias que carecían de capacidad económica para cubrir la amortización de una vivienda económica en un plazo de hasta 30 años incluidos los intereses más bajos fijados por el BHN.

La dictadura buscó "modernizar" la Región Metropolitana. Para ello promovió un plan de ordenamiento urbano. Para mejorar el aspecto urbanístico apostó a la erradicación de los asentamientos informales y a impedir su proliferación mediante la construcción de viviendas higiénicas bajo sistemas rápidos y económicos. En 1968 desde el Ministerio de Bienestar Social de la provincia de Buenos Aire se afirmó que el alto precio de los inmuebles y la falta de infraestructura favorecían la propagación de las Villas de Emergencia. Se consideró que el estado de "subdesarrollo" del interior del país originaba las migraciones internas que 
provocaban el aumento de los núcleos de viviendas "improvisadas y clandestinas". Para reducirlas se promovió la descentralización demográfica y productiva. El secretario de Estado de Gobierno, Mario Díaz Colodrero (1968), señaló que la "Revolución" debía proyectarse en todo el territorio nacional, lo que demandaba la construcción de caminos y carreteras para conectar el resto del país con el área metropolitana de Buenos Aires. En 1968 se creó el Fondo de Integración Territorial (FIT) -financiado por el Consejo Nacional del Desarrollo (CONADE)-, para la construcción de obras de infraestructura e impulsar el desarrollo industrial en Catamarca, Formosa, San Luis y Santiago del Estero.

En esa línea se inscribe la segunda etapa del PEVE, la cual consistía en el traslado de las familias "adaptadas" a las viviendas definitivas. Para ello se contemplaron las siguientes alternativas: 1) la posibilidad de traslado y su radicación en el interior del país con pasajes gratuitos, 2) la adjudicación de viviendas, en uso y habitación, mediante el pago de un canon proporcional al ingreso de los interesados, 3) la construcción de viviendas destinadas exclusivamente a los estratos bajos, mediante el pago de un canon proporcional a sus ingresos que se destinaría al Fondo de Vivienda, 4) en caso de que existiera una vivienda propia transportable, se consideraría su traslado.

\section{"El entusiasmo transforma la casa en hogar": los recursos propagandísticos de la erradicación}

En 1967 la CMV lanzó su revista oficial con el objetivo de dar a conocer el ambicioso plan de viviendas con sentido social que había emprendido la dictadura. En un reportaje de 1968 el coronel (R.E) Ulises Mario Muschietti, Director General de Políticas del Ministerio de Bienestar Social, designado Coordinador General del PEVE, declaró sobre los fundamentos sociales y políticos del PEVE. Se trataba de un plan que supuestamente apuntaba a mejorar la situación social de amplios núcleos de la población que vivían en condiciones de marginalidad. En ese sentido, los NHT implicaban una novedad en materia de políticas públicas ya que permitían facilitar la erradicación de villas de emergencia y al mismo tiempo ofrecer "condiciones de vida superiores" y permitía educar a sus habitantes para el fututo y la vivienda definitiva. Muschietti destacó como ventaja de los NHT la disponibilidad de agua, servicios cloacales, alumbrado público, luz eléctrica, alumbrado público, sendas peatonales pavimentadas, terreno en cada caso y un contrato de comodato que garantizaba su uso de forma legal. Según afirmó Muschietti el PEVE y las viviendas transitorias estaban orientadas a la promoción social integral 
DOI: $10.20396 /$ urbana.v9i3.8647231

"forjará un ambiente de progreso social" (...) esto se completará con cursillos de educación sanitaria, alfabetización y capacitación técnica para adultos, que unido a la labor constante de los Trabajadores sociales y al hecho de que se evitará totalmente el asilamiento -los niños concurrirán a las escuelas de los barrios circundantes y no habrá comercios dentro de los Núcleos-" (REVISTA DE LA CMV, 1968a: 6). ${ }^{9}$

Como parte del convenio entre el Ministerio de Bienestar Social, el Gobierno de la Provincia de Buenos Aires y la Intendencia Municipal de la Capital Federal para llevar adelante el PEVE, Muschietti mostraba, la erradicación de la Villa Progreso en Boulogne como una de las primeras labores sociales de la dictadura efectuada en el marco de la Ley 17.605. Subrayaba que sus pobladores habían sido trasladados "exitosamente" al NHT "Santa Rita", ubicado en la misma localidad. Dicho evento contó con amplia cobertura mediática (REVISTA DE LA CMV, 1968a: 8). Por ejemplo, el informe televisivo del periodista Andrés Percivale (1968) sobre el Plan Nacional de Erradicación de Villas de Emergencia, señaló que el gobierno militar estaba encontrando "una solución realmente radical" al problema habitacional. El informe enfocó un primer plano del cartel correspondiente al Plan de Alojamiento Transitorio localizado en el Barrio Santa Rita de 512 unidades habitacionales, cuya empresa constructora fue Inter American Asociados S.A. y su representante técnico era Eugenio Holmberg. Asimismo, Percivale destacó las tareas llevadas adelante por soldados del Ejército, quienes se encargaban de construir las viviendas transitorias, ayudar a las familias en su trasladado a los NHT y demoler las villas de emergencia luego de su evacuación.

El Consejo Coordinador encargado de llevar adelante el PEVE, presidido por Muschietti, elaboró un Reglamento Interno que apuntaba a regir la vida comunitaria en los NHT y la cuota que por gastos de administración y mantenimiento debían abonar los usuarios. Dicho Consejo estaba integrado por delegados de la Municipalidad de Buenos Aires, la Provincia y las Secretarías de Estado de SV, SESP, SESS y la SEPAC. En el Reglamento Interno se establecía el tipo de seguimiento que los trabajadores sociales debían realizar a las familias trasladadas a las nuevas viviendas. Dicha tarea estaba a cargo de la SEPAC y el Consejo decidió la creación de un Curso de Capacitación para Trabajadores Sociales de la Provincia de Buenos Aires (REVISTA DE LA CMV, 1968a: 8). Mediante un sistema de penas y sanciones se inspeccionaba

\footnotetext{
${ }^{9}$ El subrayado corresponde a la fuente original.
} 
el uso de la vivienda familiar y se distribuían manuales con instrucciones para su buen aprovechamiento y cuidado. Allí se incluían detalles para su limpieza interna y la conservación de los espacios comunes. Distribuía materiales que enseñaban cómo elaborar jardines y huertas individuales. Para los adultos existían cursos de alfabetización y capacitación en economía doméstica, educación cívica, laboral y familiar. La CMV promovía enfáticamente la Capacitación Laboral destinada a que los obreros y obreras aumentaran su nivel de ingresos para que pudieran acceder por sus propios medios a las viviendas definitivas. En el área de la salud, la SEPAC y la CMV Ilevaron adelante un Plan Sanitario de carácter preventivo orientado a que cada habitante de los NHT se realizara exámenes clínicos, control de vacunas y tratamientos normalizados que se complementaban con los cursos de educación sanitaria. Éstos incluían temas como higiene doméstica, higiene personal y prevención de accidentes domésticos (REVISTA DE LA CMV, 1968b: 6).

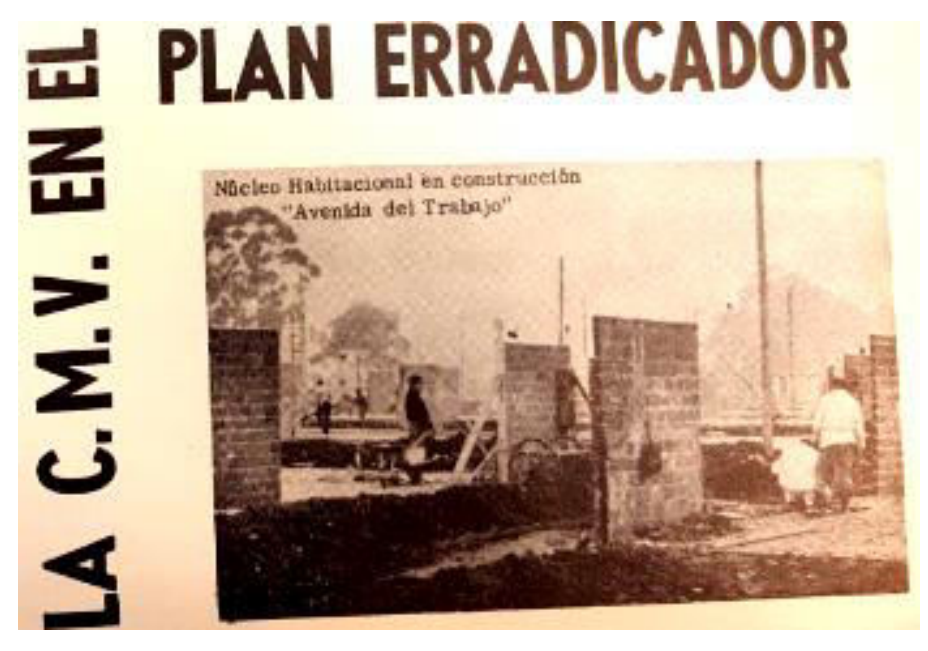

Figura 3- Propaganda del Plan de Erradicación de Villas de Emergencia en la Capital Federal Fuente: REVISTA DE LA CMV (1968b)

Desde la División Desarrollo de Comunidades de la CMV, se difundía la idea de que para el buen funcionamiento del PEVE era necesario desarrollar un profundo trabajo social con los habitantes de las villas de emergencia para reeducarlos y lograr su "adaptación" a la nueva vivienda. Una tarea que, incluso, debía desarrollarse hasta la etapa de radicación en las viviendas definitivas. Por su parte, el Director del Departamento de Planeamiento y Promoción, arquitecto Jorge Matteri sostuvo que en los últimos 20 años de construcción de vivienda masiva en Argentina no se había incluido "la programación social necesaria para la reeducación o adaptación de las personas que las habitarían" (REVISTA DE LA CMV, 1968b: 1). 
Argumentó que en varios países "desarrollados" los planes de vivienda masiva bien ejecutados fracasaron posteriormente porque no se produjo el proceso de "adaptación" necesario a las nuevas condiciones de habitabilidad. Sostuvo que en Argentina el principal problema radicaba en "el traslado de una cultura rural a una urbana". Sostuvo que el trasfondo de dicha problemática era la "inadaptación" a esa cultura urbana, que sería en la que habitarían y desarrollarían su vida comunitaria. En ese sentido, el PEVE del Onganiato adquiría una impronta "modernizante" para los sectores marginales urbanos. Con el objetivo de controlar las condiciones de habitabilidad, la CMV creó un Equipo de Administración y Mantenimiento a cargo de la División Promoción y Difusión, encargado de atender los problemas administrativos en los barrios. Matteri sostenía que ello le permitiría a los pobladores -una vez que pasen a habitar las viviendas definitivas- desempeñarse acorde a las exigencias de una "ciudad en evolución": "no sólo se puede educar dando instrucción de contenido social, sino que -al mismo tiempo- es necesario lograr que los barrios mantengan una condición mínima elemental y lógica de habitación" (REVISTA DE LA CMV, 1968b: 2).

El 29 de mayo de 1969 se produjo el estallido social conocido como el Cordobazo, en el cual confluyeron obreros y estudiantes en una enorme protesta de inédita envergadura uración contra la gestión del gobernador de la provincia de Córdoba, Carlos Caballero y las políticas económicas de Krieger Vasena que habían provocado el cierre de algunas fábricas de capital nacional e ingenios azucareros. Asimismo, su programa económico monetarista que beneficiaba a los sectores más concentrados de la burguesía nacional y trasnacional. Las devaluaciones y el congelamiento de los salarios provocaron un notable deterioro del salario real de los trabajadores. Luego de mayo de 1969 se sucedieron una serie de "azos" en Corrientes, Rosario, Mendoza, Neuquén, Alto Valle de Rio Negro y Pergamino, desestabilizaron al gobierno de Onganía. Ese clima de protesta, movilización y radicalización demostró que para perpetuarse en el poder no alcanzaba con el control de las agencias administrativas y del aparato de coacción, sino que era crucial la adhesión de los "gobernados". También le recordó a las clases dominantes la imposibilidad de construir un proyecto de dominación con pretensiones hegemónicas excluyendo al sindicalismo. En ese clima de tensión, Onganía solicitó la renuncia a todos los Ministros y Secretarios de Estado y anunció el "tiempo social", como recurso para contener las demandas de los obreros (LA NACIÓN, 1969; CLARÍN 1968, 1969). 
Paralelamente, el gobierno continuaba con los desalojos de familias en distintos puntos de la Ciudad de Buenos Aires. ${ }^{10}$ Organizaciones como la Federación de Barrios y Villas de Emergencia resistieron a dichas erradicaciones, lo que evitó, por ejemplo, el desalojo de la Villa de Retiro. Tras la ruptura de la Confederación General del Trabajo (CGT) en 1968, los dirigentes de la Federación estrecharon lazos con la CGT de los Argentinos y el Movimiento de Sacerdotes del Tercer Mundo. La dictadura buscó su desintegración por la fuerza, ya que únicamente consideraba legítimas a las organizaciones vecinales que avalaban las acciones del Ministerio de Bienestar Social. Posteriormente, se acercaron a los sectores más radicalizados del peronismo, que dio lugar al Frente Villero de Liberación Nacional en 1972 y luego al Movimiento Villero Peronista (BELLARDI \& DE PAULA, 1986: 64-76).

En ese contexto de tensión social, el gobierno militar incrementó los recursos propagandísticos que apuntaban a mostrar su vocación social. Por ejemplo, en 1969 la Secretaría de Estado de Vivienda publicó un cuadernillo de carácter propagandístico, titulado Imágenes de Vivienda. Allí se sintetizaban los "logros" del Plan de Erradicación de Villas de Emergencia. Los NHT aparecían como el inicio de una nueva etapa y una "mejor vivienda". Tal como se observa en la figura No 4, el documento afirmaba que los NHT aportaban "nuevas formas de vida y expansión para la niñez y la juventud" ya que sus plazas ofrecían "amplias" ventajas de esparcimiento.

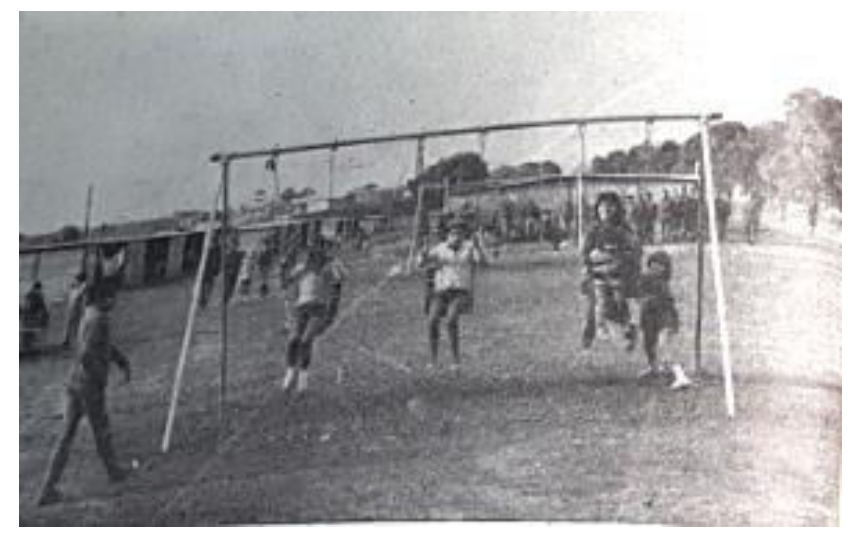

Figura 4- Espacio verde rodeado de NHT

Fuente: SECRETARÍA DE ESTADO DE VIVIENDA (1969:66)

\footnotetext{
${ }^{10}$ El 15 de agosto de 1968, la CMV erradicó a 489 personas que habitaban en las 72 viviendas de la Villa de Emergencia No 4. En 1969 se erradicaron 4.034 personas de distintas villas, siendo la No 5 la más poblada con 2.773 personas que fue erradicada el 27 de septiembre de 1969 . En 1971 se desalojaron 270 habitantes de la Villa No 18 para la construcción de las viviendas del conjunto habitacional Parque Almirante Browm "C". El 22 de septiembre de 1972, se desalojó a 9.305 personas en la Villa No 2 (DE LA TORRE, 2008:160-161).
} 
Imágenes de Vivienda se refería a los NHT (figuras No 4, 5 y 6) como la verdadera "transformación en Hogar", ya que la nueva vivienda era producto del "nuevo sentimiento de superación" (SECRETARÍA DE ESTADO DE VIVIENDA, 1969:64).

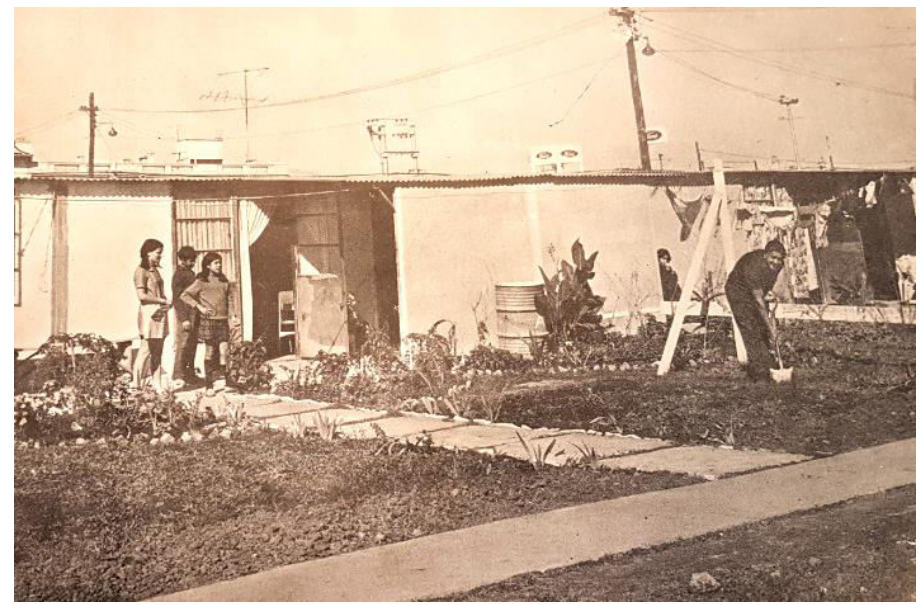

Figura 5- Plan de Erradicación de Villas de Emergencia. Núcleo Habitacional Transitorio "Santa Rita"

Fuente: SECRETARÍA DE ESTADO DE VIVIENDA (1970:63).

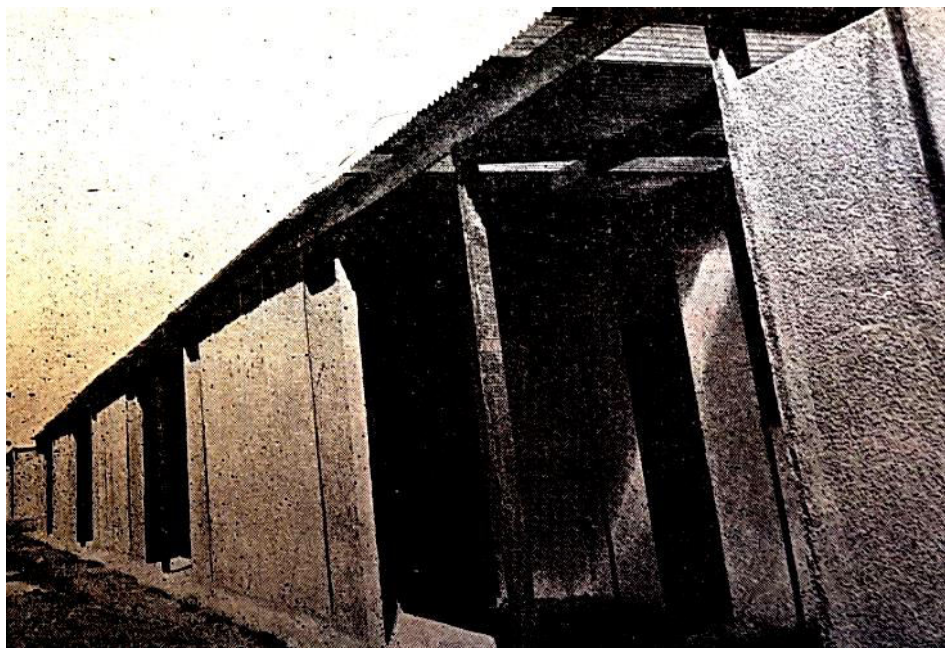

Figura 6- Plan de Erradicación de Villas de Emergencia. Núcleo Habitacional Transitorio "Ezpeleta"

Fuente: SECRETARÍA DE ESTADO DE VIVIENDA (1970:55). 
Dicho documento destacó el "compromiso social" que asumió el Ejército en la "transformación social". Por eso, se le rindió homenaje al Batallón de Ingenieros de Construcciones 601 su labor en la primera etapa del PEVE, correspondiente al traslado las familias a los NHT o transitorias. Se celebró una misa especial y se le otorgó una placa conmemorativa (Figura No 7).

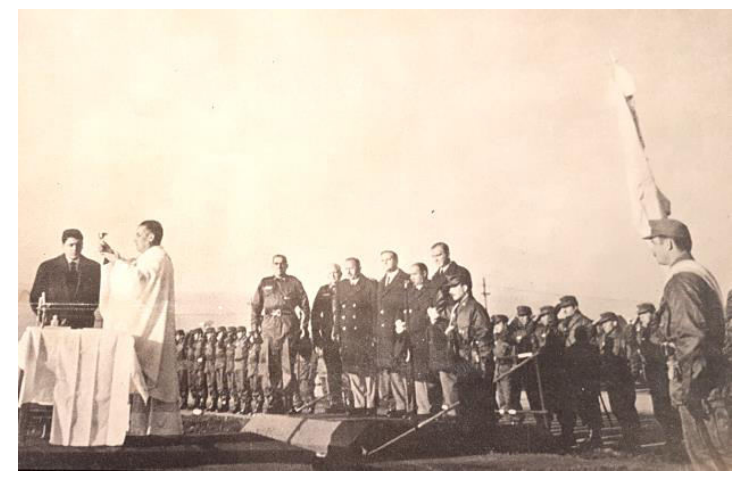

Figura 7- Homenaje al Batallón de Ingenieros de Construcciones 601 Fuente: SECRETARÍA DE ESTADO DE VIVIENDA (1969:66)

La participación del Ejército en dichas tareas le permitía al gobierno militar reforzar la imagen positiva de los militares ante la sociedad civil. Asimismo, en el documental propagandístico de la "Revolución Argentina" Ilamado Tres años de Gobierno que difundió el Noticiero Panamericano (1969: No 1517) de Argentina Sono Film -empresa cinematográfica dirigida por Ángel Mentasti-, se enfatizaba en los beneficios de la erradicación de villas de emergencia, entendidas como espacios de promiscuidad y degeneración de los valores éticos, morales y sociales (Figura No 8). En ese sentido, tanto en Tres años de Gobierno como en el cuadernillo Imágenes de Vivienda, se observa cómo los soldados y principalmente el Comando de Ingenieros del Ejército a cargo del Jefe de Operaciones coronel José Alfredo Bianchi, participaban "activamente" en las tareas de erradicación. Como señala Divinzenso (2017) en esos años el Ejército se abocó a promover su participación en una serie de actividades que denominó "Acción Cívica". Se trataba de una serie de tareas donde participaban conjuntamente civiles y militares en actividades educativas, deportivas y sanitarias. Mediante la "Acción Cívica" se pretendía que las fuerzas del orden incrementaran su visibilidad y aceptación en la sociedad civil social. Como parte de la "Acción Cívica", su participación en la erradicación de villas miseria formó parte de las estrategias de legitimación que apuntaba a reforzar la "vocación social" de la "Revolución Argentina". 


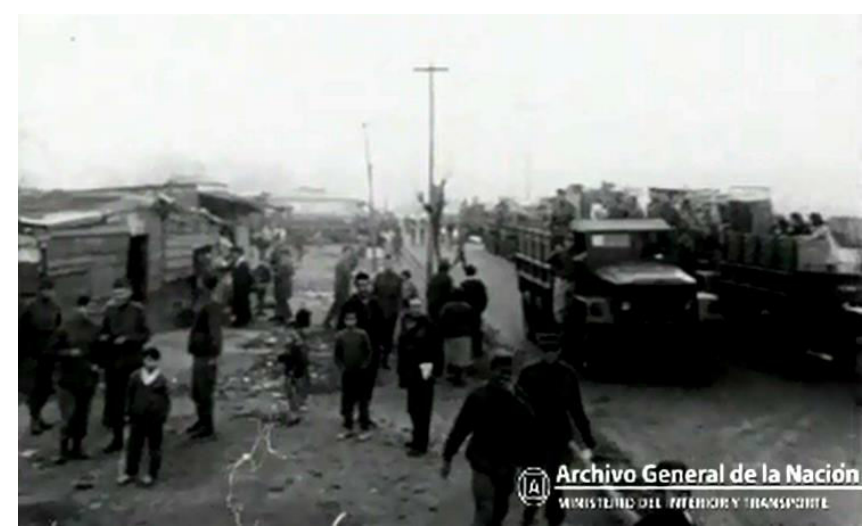

Figura 8- El Ejército y el PEVE

FUENTE: Noticiero Panamericano (1969).

Asimismo, la dictadura promovió la producción de documentales cinematográficos de propaganda oficial. Desde el Ministerio de Bienestar Social se le encargó a un grupo de cineastas independientes la elaboración de cortometrajes propagandísticos, que dieran cuenta de la acción social del gobierno militar hacia los sectores más humildes en materia de vivienda y salud pública. Allí se inscribe el documental El principio del Fin (1970) dirigido por Ricardo Alventosa. ${ }^{11}$ Su principal argumento radicó en mostrar cómo los NHT habían "revolucionado" la vida de los habitantes de las villas. El discurso giró en torno a los "beneficios" de la erradicación y las ventajas culturales y materiales que ofrecían las viviendas transitorias, entendidas como un instrumento de transformación e "integración social" a la vida urbana: "en la nueva vivienda se pertenece a un barrio de la cuidad y no a un grupo de casillas" (ALVENTOSA, 1970, min. 12:05). En las largas tomas que enfocaban la vida cotidiana en las villas, se mostraba imágenes seguidas de música melancólica de fondo de los adultos mayores con problemas de alcoholismo y a los niños tristes. Una vez que las familias eran instaladas en los NHT los niños aparecían "felices y jugando" y esas imágenes iban acompañadas de música alegre.

Si bien hubo pobladores que se mostraron entusiasmados con la posibilidad de adquirir una vivienda propia y simpatizaban con los NHT, otros desconfiaban del gobierno militar por

\footnotetext{
${ }^{11}$ Alventosa fue un reconocido largo metrajista de la denominada Generación del sesenta, fue presidente de la Asociación de Realizadores de Cortometraje (ARCM). Luego fundó su agencia publicitaria y tuvo una importante trayectoria en el cine publicitario. Por encargo de la Secretaría de Salud Pública realizó El mal de los rastrojos (1969), Salud rural (1969) y Mal de chagas (1970) Operativo agua (1970) y Cuando llega la enfermedad (1970) (RAMÍREZ LLORENS, 2016, p. 35). El principio del fin tiene una duración de 15:23 minutos. Su producción estuvo a cargo de Miguel Perro, Isabel Perera y Raúl Rodríguez. El guionista fue Horacio Bichelbaum y en la compaginación estuvo Miguel Pérez y Oscar Oliverio como ayudante de dirección. La música del film fue de Astor Piazzola.
} 
considerar que no ofrecía suficientes certezas ni soluciones concretas para mejorar su situación habitacional, sino que su política se reducía a "sacarlos de su tierra". Por ejemplo, Andrés Percivale (1968) en su informe periodístico entrevistó a los pobladores de los nuevos barrios $(\mathrm{NHT})$, quienes decían sentirse "muy contentos" e "impresionados" por lo "maravilloso" del barrio y la "comodidad" para viajar a sus trabajos: "las casas son muy lindas e higiénicas", señalaba uno de los vecinos entrevistados. En el documental se destacaba que los NHT parecían haber solucionado las largas horas de espera para llenar los baldes de agua para la higiene familiar: "frente a los planes de erradicación de villas de emergencia suele creerse que la mudanza a los nuevos alojamientos, es una especie de milagro que cambia en pocas horas la suerte de miles de personas" (ALVENTOSA, 1970, min. 2:05-2:25). Era recurrente la imagen de los niños disfrutando del acceso al agua por una simple canilla. Si bien en el documental se hacía referencia al escaso confort que ofrecían los NHT, se enfatizaba en el acceso a los servicios esenciales que no se tenían en las villas, como agua potable, luz e intimidad hogareña: "ello posibilitará el verdadero disfrute de las viviendas definitivas, porque Ios NHT permiten atacar el problema social" (ALVENTOSA, 1970, min. 13:36-13:49).

Como parte de la "readaptación social" que se pretendía instalar desde los NHT, a cada familia le correspondía un terreno. El principio del fin muestra muy bien la importancia que se le otorgaba al alambrado y al cerco (Figura No 9), ya que servían para delimitar el espacio propio y el del vecino: "lo transitorio de la ocupación no quita el sentido de lo propio" (SECRETARÍA DE ESTADO DE VIVIENDA, 1969). Se apuntaba a fomentar el respeto por la propiedad privada y el cuidado de los espacios cotidianos, una condición necesaria para pasar a las viviendas definitivas, esa "nueva vida se va ganando lentamente, sin milagros" (ALVENTOSA, 1970).

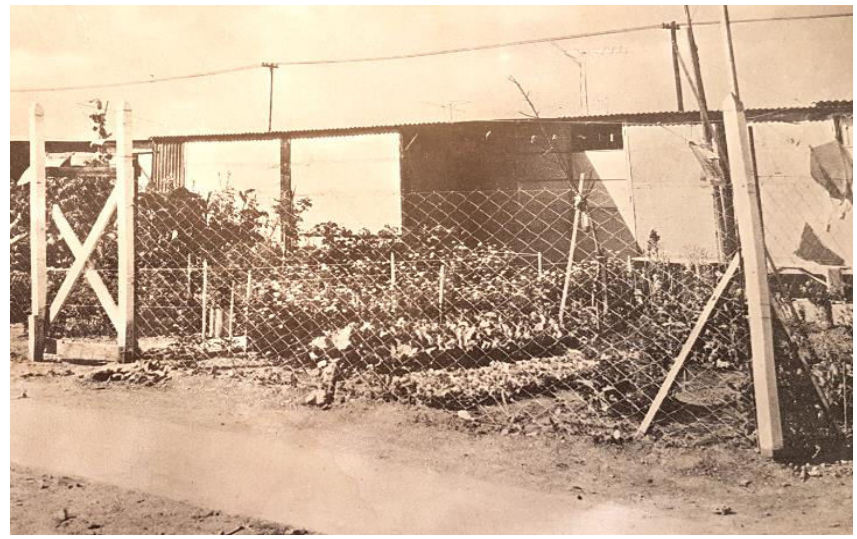

Figura 9- Imagen de los NHT

Fuente: SECRETARÍA DE ESTADO DE VIVIENDA, 1969. 
Supuestamente, los NHT ofrecían como "ventajas" dos servicios importantes: las guarderías infantiles para las madres que trabajaban y los Centros de alfabetización para adultos. Lo demás estaba afuera del barrio. Se suponía que eso "motivaría" a los pobladores a "salir" y "conectarse" con el resto de la "comunidad". De ese modo, lo que a simple vista parecía una falencia, en el documental se mostraba como una ventaja de la política social del régimen: "no hay salas de primeros auxilios, ni escuelas exclusivas para los NHT, pero nunca el nivel de salud fue tan alto, ni la concurrencia de niños a la escuela tan amplia" (ALVENTOSA, 1970, min. 12:51- 13:12). La acción social del Estado aparece representada en el trabajo de los médicos en las salas de primeros auxilios, los trabajadores sociales, los maestros de los cursos de alfabetización, el Comando de Ingenieros y los camiones del Ejército que "colaboraban" en el traslado de las familias de forma "gratuita". Asimismo, el documental mostraba que una de las "ventajas" que ofrecía el Plan de Erradicación era la posibilidad de que las familias retornaran a sus provincias de "origen". Se mostraban imágenes de familias "felices y ansiosas" que abordaban un tren "cómodo" y con buena comida para emprender su retorno, cuando bien se sabe que muchas fueron expulsadas por la fuerza.

La principal tarea de los trabajadores sociales era "inducir" el cambio y el documental finaliza con una escena donde el jefe de familia manifestaba su "voluntad de cambio": "se levantó a la madrugada el día de la mudanza para quemar su casilla con sus propias manos, en ese momento también se están echando los cimientos de lo que sería su vivienda definitiva" (ALVENTOSA, 1970, min. 13:56-15:05). Allí se señala, que ese "cambio" era meramente individual, cuyo "motor" era el "deseo genuino" de "salir" de la villa. Esa búsqueda por la "readaptación y resocialización" nos indica que para el régimen el problema de la vivienda era ante todo, un problema cultural. Ese tipo de discurso estaba socialmente instalado e incluso, reforzado por algunos periodistas de los medios masivos.

En otro reportaje para el programa televisivo Telenoche sobre la Erradicación de las Villas de Emergencia, la periodista Mónica Mihanovich (1970) interrogó a dos hombres y mujeres que habitan en una de las villas. Les preguntó por qué no estaban "dispuestos" a dejar sus "casillas" y mudarse a los nuevos barrios de erradicación:

Mónica Mihanovich (MM): ¿Usted considera que vale la pena vivir en la villa? Reportaje a una mujer pobladora (RM): No, no considero.

MM: ¿Qué haría usted?

RM: Bueno, como le dije, trataría, haría todo lo posible para que aunque sea despacito, buscarme un pedacito de tierra y poner ahí mi casa. 
MM: ¿Por qué es que la gente no se quiere ir en general de las villas de emergencia?

RM: Mire, yo no comprendo por qué es.

MM: ¿Por qué a todos les pasa lo mismo?

RM: No sé, no me explico.

MM: ¿Pero qué ventajas tiene quedarse aquí?

RM: Acá no hay ninguna, yo no la veo. Acá la única ventaja es sufrir, sufre las moscas, sufre los mosquitos, porque ya se da una idea usted de como uno está. Eso es lo que pasa. El agua, cuando viene acá se pasa adentro, por lo menos yo sufro eso.

MM: ¿Usted cree que la gente tendría que mudarse o hacer un esfuerzo para ir a un barrio realmente con casas hechas como se debe?

RM: y si, si es por mí pueden hacerlo [sic]

Reportaje a un hombre poblador (RH): ¿Señor, hace cuanto que vive aquí?

$\mathrm{RH}: 12$ años

MM: ¿Si usted tuviera la oportunidad de irse, se iría?

$\mathrm{RH}$ : Si, como no.

MM: ¿Por qué no se ha ido hasta ahora?

RH: y no, no me alcanza el dinero.

MM: ¿No hay manera de anotarse o de inscribirse en alguno de los nuevos barrios que hay?

RH: Si, puede ser.

MM: ¿no lo va hacer?

RH: isi, como no!

MM: ¿Por qué cree que la gente se queda aquí, por comodidad o por qué?

$\mathrm{RH}$ : porque son pobres y no les alcanza para comprarse un terreno.

MM: ¿Sin embargo hay mucha gente que son pobres, no les alcanza, pero tampoco se anotan para que los ayuden, por qué es eso?

$\mathrm{RH}$ : la verdad es que no estoy, no [sic]. ${ }^{12}$

Como se observa en dicho reportaje se reforzaba el supuesto de que vivir en una villa era producto de la "comodidad" de sus pobladores. En otra entrevista dirigida a una mujer soltera y madre de cuatro hijos, ella afirmó que si la sacarían de la villa, se iría. Al respecto, Mihanovich (1970) le preguntó:

\footnotetext{
${ }^{12}$ El subrayado es nuestro.
}

(c) Urbana: Rev. Eletrônica Cent. Interdiscip. Estud. Cid. Campinas, SP $\quad$ v.9, n.3 [17] $\quad$ p.677-711 $\quad$ set./dez. 2017 
MM: ¿Y usted haría un esfuerzo, usted trataría de poder conseguir algún dinero para pagar una cuota o para ir a uno de los barrios de erradicación o no?

RM: y no, la verdad es que yo trabajo en una casa de familia por hora y la verdad que no me alcanza en mi [sic], me alcanza no más para darle de comer a mis hijos no más, porque yo soy sola, la única que trabaja para ellos soy yo.

MM: y ¿Si esta casilla se le quemara, usted querría volver a construirla acá o no ${ }^{13}$

RM: no, la verdad me iría en [sic] otro lado donde sea mejor.

Claramente, dichos reportajes deben ser situados en un contexto de fuerte resistencia social a las erradicaciones por falta de confianza en el régimen, el cual no escatimaba en la represión. La política de erradicación fue extremadamente violenta en términos físicos y simbólicos y provocó fuertes trastornos psico-emocionales debido los pobladores sufrían la pérdida de sus bienes materiales y de sus lazos comunitarios que sostenían el tejido social de su vida cotidiana. Como se observan en las figuras 4,5 y 8 los sujetos sociales que predominaban en los primeros planos de los documentales propagandísticos eran hombres del Ejército, niños y mujeres, las cuales aparecen realizando tareas domésticas. La presencia de hombres es poco significativa y por lo general aparecen colaborando en erradicación y el mejoramiento de los barrios junto a los soldados.

\section{Reflexiones finales}

A lo largo de este trabajo hemos visto que la erradicación de villas de emergencia fue una política compartida por gobiernos civiles y militares desde 1956 en adelante. La "Revolución Argentina" entendió que la expansión de la pobreza urbana era un problema de Seguridad Nacional ya que favorecía la penetración del "enemigo" comunista, por lo que su erradicación se convirtió en una prioridad. Todo ello debe ser leído en el marco del contexto marcado por el crecimiento exponencial de las metrópolis latinoamericanas que llevó a que la población urbana superara ampliamente a la rural. Este proceso fue acompañado por el incremento de la pobreza urbana en las periferias. A partir de los años cincuenta, comenzaron a implementarse en Argentina, Brasil y Chile los primeros programas de erradicación de asentamientos informales -conocidos por una pluralidad de términos: callampas o poblaciones (Chile), cantegriles (Uruguay), favelas (Brasil), villas miseria (Argentina)- en las ciudades de Buenos Aires, Santiago de Chile y Río de Janeiro, entre otras. Durante los años sesenta, el patrón común del Cono Sur fue el incremento de la configuración de la ciudad informal,

\footnotetext{
${ }^{13}$ El subrayado es nuestro.
}

(c) Urbana: Rev. Eletrônica Cent. Interdiscip. Estud. Cid. Campinas, SP $\quad$ v.9, n.3 [17] $\quad$ p.677-711 set./dez. 2017 
producto del aumento de la segregación urbana, que implicó la ocupación del espacio a partir de la expansión de los asentamientos informales.

En el caso de la dictadura militar de 1966, tanto las viviendas definitivas como las transitorias (NHT) fueron concebidas como un dispositivo de control social, que apuntó a normalizar los modos de habitar y los comportamientos sociales de los pobladores. De ese modo, la normalización de los usos de los espacios de las viviendas transitorias tuvo por finalidad evitar la superposición de funciones. Así, la vivienda individual separaba las familias lo que suponía que evitaría la promiscuidad. Se apuntó a inculcar valores asociados al cuidado de la casa propia, la intimidad hogareña y la profilaxis urbana: mantener la casa limpia, sin chapas ni carteles y el respeto por la propiedad privada de manera que los pobladores aprehendieran sobre los beneficios de convertirse en propietarios. Así, se buscó reeducar y resocializar a los sectores populares e imponer modos "modernos" de habitar de una "ciudad en evolución". De acuerdo al principio de subsidiariedad del Estado, se apeló a valores como el estímulo y el deseo por el auto-desarrollo, la transformación y el cambio personal. Si bien se reconocía que el déficit habitacional era un problema social, la insistencia en la participación de los propios individuos como instrumento para "combatir" el paternalismo, terminó por responsabilizarlos de su condición de "subdesarrollo". Como vimos, este tipo de iniciativas convivió con otras políticas que apuntaron a fomentar la autoconstrucción y participación popular directa e incluyó la conformación de cooperativas de viviendas fomentadas por funcionarios del Ministerio de Bienestar Social.

Pese a que los NHT no sirvieron para solucionar los problemas de hacinamiento, ya que su tamaño era estándar y no era adaptable al número de integrantes de las familias, la dictadura hizo de ese tipo de viviendas una política social "moderna". La dictadura utilizó los NHT con fines propagandísticos, para mostrar la imagen de un gobierno que no se "olvidaba de los pobres" y que seguía los patrones arquitectónicos de la vanguardia internacional en materia habitacional.

Como se sabe, vivienda es un término técnico que remite a la necesidad básica de abrigo y al ámbito donde se realiza la reproducción de vida biológica. Obviamente dichas especificidades varían conforme a las pautas culturales e históricas de cada sociedad. Asimismo, los diferentes tipos de viviendas implican distintos modos de habitar, ya que varían las formas de relación entre las personas, los objetos y el espacio urbano. En cambio, casa alude al espacio íntimo de habitar, de construcción de subjetividades y al universo de las representaciones. En la casa la "gente común" despliega la parte privada de su cotidianeidad (ARMUS \& HARDOY, 1990: 156). Asimismo, en el espacio urbano se manifiesta la vivencia 
cotidiana de cada ser que se relacionan entre sí individual y colectivamente en un territorio determinado (HONORATO, 2013: 192). En cuanto a las "maneras de habitar" un barrio, De Certeau (1980) se interesó por las prácticas culturales de los usuarios en el barrio, en tanto espacio público donde trascurre la "escenificación de la vida cotidiana", mientras que el acto de cocinar se ubica en el espacio privado de la familia. Mediante sus acciones específicas ("tácticas") el usuario domina la separación entre el espacio público y el privado, como condición de posibilidad de despliegue de la vida cotidiana en el espacio urbano. En ese sentido, mediante los NHT se apuntó a transformar radicalmente la vida cotidiana de los sectores populares. Si bien se les impusieron nuevas pautas culturales, algunos pobladores se apropiaron de dichos valores, al menos entre quienes aceptaron ser erradicados por considerar que eso mejoraría sus condiciones materiales de vida. Como se sabe, muchos pobladores no confiaban en las supuestas "bondades" del régimen y se resistieron al abandono de sus viviendas. En esos casos, el gobierno militar aplicó la erradicación con altos niveles de arbitrariedad y violencia.

Hemos visto que el régimen persiguió con ansias múltiples estrategias para mostrarse "moderno" de cara al mundo y se auto-asignó la tarea de "modernizar" a los sectores populares urbanos. De ahí la importancia que tuvieron los recursos propagandísticos ya sea tanto las imágenes fotográficas producidas por encargo de la propia dictadura como el documental El principio del Fin de Alventosa. Allí se observa la intención del régimen por mostrar a niños, mujeres y familias "felices" y a hombres "dignificados" debido a los "beneficios" y ventajas materiales que ofrecían las viviendas transitorias mediante la erradicación. En ese sentido, los NHT fueron presentados como instrumentos para la "verdadera" transformación e "integración" social. Todo ello respondía a las pretensiones refundacionales y modernizadoras del régimen y su aspiración por transformar radicalmente la vida cotidiana de los pobladores y modernizar la estructura urbana de la ciudad.

Si bien desde el plano discursivo, la política del régimen desde el Ministerio de Bienestar Social, estuvo orientada a reducir el déficit habitacional en los estratos más bajos de la sociedad urbana, los instrumentos financieros que se optaron terminaron por fortalecer la industria de la construcción, los sectores concentrados de la economía vinculados a ella, la banca privada y a los propietarios de suelo. De ese modo, el impacto fue mucho menor en el proceso de producción y distribución de las viviendas en los estratos bajos. 


\section{Referencias bibliográficas}

ABOY, Rosa (2017). Villas Miseria, Favelas y Asentamientos: nuevas rutas en Historia Urbana. Urbana. Revista do Centro Interdisciplinar de Estudos sobre a Cidade, 9 (1), pp. 1-14. Disponible en: https://periodicos.sbu.unicamp.br/ojs/index.php/urbana/issue/view/922. Acceso: 14 noviembre 2017.

AGOSTINIS, Silvia, BELLARDI, Marta, GAZZOLI, Rubén y PASTRANA, Ernesto (1995). Vivir en un cuarto inquilinatos y hoteles en el Buenos Aires actual. Buenos Aires: Instituto Internacional de Medio Ambiente y Desarrollo de América Latina.

ALMADA, Héctor, ARMUS, Diego, CASTELLS, Julia, CUENYA, Beatriz, DI LORETO, María y PEÑALVA, Susana (1984). Condiciones de hábitat y salud de los sectores populares. Un estudio piloto en el asentamiento San Martín de Quilmes. Buenos Aires: Centro de Estudios Urbanos y Regionales.

ALVENTOSA, RICARDO (1970). El principio del fin. Buenos Aires: Ministerio de Bienestar Social.

ALVAREZ, Manuela Luz (2017). Organizaciones villeras y Estado. El movimiento villero peronista frente a la aplicación del Plan laborada en la Ciudad de Buenos Aires (1973-1974). Urbana. Revista do Centro Interdisciplinar de Estudos sobre a Cidade, 9 (1), pp. 148165.

ÁLVAREZ DE CELIS, Fernando (2005). El sur en la Ciudad de Buenos Aires: caracterización económica territorial de los barrios de La Boca, Barracas, Nueva Pompeya, Villa Riachuelo, Villa Soldati, Villa Lugano y Mataderos. Buenos Aires: Centro de Estudios para el Desarrollo Económico Metropolitano (CEDEM).

ARMUS, Diego y HARDOY, Jorge (1990). Conventillos, ranchos y casa propia en el mundo urbano del novecientos. In ARMUS, Diego (Ed.), Mundo urbano y cultura popular: Estudios de historia social argentina. Buenos Aires: Editorial Sudamericana, 155-193. 
AUYERO, Javier y HOBERT, Rodrigo (2007). "¿Y esto es Buenos Aires?" Los contrastes del proceso de urbanización. In: JAMES, Daniel (Comp.), Violencia, proscripción y autoritarismo (1955-1976). Buenos Aires: Sudamericana, 213-244.

BALLENT, Anahí (2004). Conjuntos habitacionales. En LIERNUR, Jorge y ALIATA, Fernando (Eds.), Diccionario de arquitectura en la Argentina. Buenos Aires: Clarín, 143-147.

BALLENT, Anahí y LIERNUR, Francisco (2014). La casa y la multitud. Vivienda, política y cultura en la Argentina moderna. Buenos Aires: Fondo de Cultura Económica.

BARRIOS, Romina (2012). El Plan de Realojamiento de la Villa 7 en Mataderos, en Ciudad de Buenos Aires, entre 1971 y 1975. Tesis para optar el grado de Magíster en Administración Pública. Buenos Aires: Facultad de Ciencias Económicas, Universidad de Buenos Aires.

BELLARDI, Marta, \& DE PAULA, Aldo (1986). Villas Miseria: origen, erradicación y respuestas populares. Buenos Aires: Centro Editor de América Latina.

CASTELLS, Manuel (1974). La cuestión urbana. Madrid: Siglo XXI.

CLARÍN (1967). Buenos Aires (11 octubre).

CLARÍN (1967). Buenos Aires (14 octubre).

CLARÍN (1967). Buenos Aires (15 octubre).

CLARÍN (1967). Buenos Aires (17 octubre).

CLARÍN (1967). Buenos Aires (18 octubre).

CLARÍN (1967). Buenos Aires (13 octubre).

CLARÍN (1968). Buenos Aires (10 agosto), p. 14.

(c) Urbana: Rev. Eletrônica Cent. Interdiscip. Estud. Cid. Campinas, SP $\quad$ v.9, n.3 [17] $\quad$ p.677-711 set./dez. 2017 
CLARÍN (1969). Buenos Aires (10 junio), p. 22.

CLARÍN (1969). Buenos Aires (13 junio), p. 23.

COLODRERO, Mario Díaz (1968). Discurso pronunciado por la Red de Radio y Televisión. Buenos Aires: Secretaría de Estado de gobierno, Dirección General de Provincias, Departamento de Difusión Provincial (15 marzo).

COMISIÓN MUNICIPAL DE LA VIVIENDA (1970). Núcleos Habitacionales Transitorios. Buenos Aires: Municipalidad de la Ciudad de Buenos Aires.

CRAVINO, María Cristina (2009). Entre el arraigo y el desalojo: la Villa 31 de Retiro. Derecho a la ciudad, capital inmobiliario y gestión urbana. Los Polvorines: Universidad Nacional de General Sarmiento.

DÁVALOS, Patricia, JABBAZ, Marcela y MOLINA, Estela (1987). Movimiento villero y Estado, 1966-1976. Buenos Aires: Centro Editor de América Latina.

DE CERTEAU, Michel (1980). La invención de lo cotidiano. Habitar, cocinar. México: Universidad Iberoamericana, Departamento de Historia.

DE ÍMAZ, José Luis (1977). Promediados los cuarenta. Buenos Aires: Sudamericana.

DE LA TORRE, Lidia (2008). Buenos Aires: del conventillo a la Villa Miseria (1869-1989). Buenos Aires: Editorial de la Universidad Católica Argentina.

DIVINZENSO, Alicia (2017). La "Acción Cívica" del Ejército argentino: características, modalidades y planificación de una estrategia de legitimación. 1966-1975. In: Páginas. Revista digital de la Escuela de Historia de la Universidad Nacional de Rosario, 9 (19), pp. 75-97.

EL MERCURIO (2007). Santiago de Chile (24 octubre).

(c) Urbana: Rev. Eletrônica Cent. Interdiscip. Estud. Cid. Campinas, SP $\quad$ v.9, n.3 [17] $\quad$ p.677-711 set./dez. 2017 
FREI MONTALVA, Eduardo. Esfuerzo de todo un pueblo. Discurso al anunciar el Programa de Promoción Popular, Conferencia de Prensa, 10 de diciembre de 1964. Disponible en: http://www.archivochile.com/Gobiernos/gob_edo_freim/de/GOBdefreim0007.pdf. Acceso: 07 mayo, 2015.

GARCÍA, Marina (2015). El proceso de erradicación de villas. El caso de Puerta de Hierro en el partido de La Matanza (1966-2013). In: II Jornadas de Historia Reciente del Conurbano Bonaerense, Los Polvorines.

GAZZOLI, Rubén (2007). Vivienda social. Investigaciones, ensayos y entrevistas. Buenos Aires: Nobuko.

GOMES, Gabriela (2011). El Onganiato y los sectores populares: funcionarios, ideas y políticas de la Secretaría de Estado de Promoción y Asistencia a la Comunidad (1966-1970). In: Anuario del Centro de Estudios Históricos "Prof. Carlos S. A. Segreti", Año 11, n 11, 279-302.

GOMES, Gabriela (2014). Los orígenes doctrinarios de la propuesta comunitarista del gobierno de Juan Carlos Onganía. In: GALVÁN, Valeria \& OSUNA, Florencia (Comp.), Política y cultura durante el "Onganiato". Nuevas perspectivas para la investigación de la presidencia de Juan Carlos Onganía (1966-1970). Rosario: Prohistoria, 105-119.

GOMES, Gabriela (2016a). Las políticas sociales de los regímenes dictatoriales en Argentina y Chile (1960-1970). Buenos Aires: FaHCE/UNLP, UNaM, UNGS.

GOMES, Gabriela (2016b). Las trayectorias políticas de los funcionarios nacionalcorporativistas durante el Onganiato. In GOMES, Gabriela \& VICENTE, Martín (Eds.), Trayectorias de Intelectuales en el Estado. Actas de Jornadas, 33-57.

GIORGI, Guido Ignacio (2014). Refundar la sociedad. El comunitarismo como política de Estado en el Gobierno de Onganía. In: GALVÁN, Valeria \& OSUNA, Florencia (Comp.), Política y cultura durante el "Onganiato". Nuevas perspectivas para la investigación de la presidencia de Juan Carlos Onganía (1966-1970). Rosario: Prohistoria, 119-139. 
GUAIA, Esteban (1968). Lineamientos de una política de vivienda. Buenos Aires: Ministerio de Bienestar Social, Secretaría de Estado de Vivienda.

HONORATO, Cezar (2013). Anotações acerca da questão urbana contemporânea. In: Passagens. Revista Internacional de História Política e Cultura Jurídica, 5 (1), 84-101.

LA NACIÓN (1969). Buenos Aires (21 junio).

LA NACIóN (2007). Buenos Aires (29 enero).

MASSIDDA, Adriana Laura (2017). Negociaciones, permanencia y construcción cotidiana en villas: villas la lonja, cildáñez y castañares, Buenos Aires, 1958-1967. In: Urbana. Revista do Centro Interdisciplinar de Estudos sobre a Cidade, 9 (1), 15-46.

MIHANOVICH, Mónica (1970). Nota periodística sobre la erradicación de las villas de emergencia. Archivo Privado DiFilm. Buenos Aires (14 enero).

[https://www.youtube.com/watch?qw=UaEWHGXQ3WY

MINISTERIO DE BIENESTAR SOCIAL (1968a). La participación social en el proceso de desarrollo de la comunidad. La Plata: Provincia de Buenos Aires.

MINISTERIO DE BIENESTAR SOCIAL (1968b). Manual de Acción Comunitaria. Buenos Aires: Secretaría de Estado de Promoción y Asistencia a la Comunidad.

MINISTERIO DE BIENESTAR SOCIAL (1968c). Criterios de normalización en matera de planeamiento del desarrollo de la comunidad. La Plata: Provincia de Buenos Aires.

MINISTERIO DE BIENESTAR SOCIAL (1968d). Plan de erradicación de las villas de emergencia de la Capital Federal y del Gran Buenos Aires. Buenos Aires: Ministerio de Bienestar Social.

MINISTERIO DE BIENESTAR SOCIAL (1969). Primera Conferencia Interamericana sobre cooperativismo. Buenos Aires: Dirección Nacional de Cooperativas (4 al 8 noviembre). 
MOLINERO, Carmen (2005). La captación de las masas: política social y propaganda en el régimen franquista. Madrid: Cátedra.

NOTICIERO PANAMERICANO (1969). Tres años de Gobierno. Buenos Aires: Departamento de Documentos de Cine, Audio y video del Archivo General de la Nación.

O 'DONNELL, Guillermo (2009). El Estado burocrático autoritario. Buenos Aires: Prometeo.

ONGANÍA, Juan Carlos (1967). La Nación. Buenos Aires (7 julio).

PERCIVALE, Andrés (1968). Informe periodístico del Plan nacional de erradicación de villas de emergencia 1968. Archivo Privado Difilm. Buenos Aires (21 marzo). [https://www.youtube.com/watch?v=CVsYDpf-L78]

PRIMERA PLANA (1968). Buenos Aires (No 276, 9 abril), 14-16.

PRIVITELLIO, Luciano y ROMERO, Luis Alberto (2005). Organizaciones de la sociedad civil, tradiciones cívicas y cultura política democrática: el caso de Buenos Aires, 1912-1976. In: Revista de Historia, Año I, No1.

[http://www.unsam.edu.ar/escuelas/politica/centro_historia_politica/material/privitelio.pdf]

RAMÍREZ LLORENS, Fernando (2016). Cortometraje independiente y documental estatal durante el gobierno de Onganía. In: Revista Cine Documental (13), 24-53.

[http://www.cinedocumental.com.ar/revista/pdf/13/13-Art2.pdf].

REVISTA DE LA CMV (1968a). Buenos Aires (No 12, Julio).

REVISTA DE LA CMV (1968b). Buenos Aires (No 13, junio).

SCIRICA, Elena (2010). Visión religiosa y acción política. El caso de Ciudad Católica -Verbo en la Argentina de los años sesenta. PROHAL Monográfico, Revista del Programa de Historia de América Latina, Vol. 2, no 2, 26-56.

(c) Urbana: Rev. Eletrônica Cent. Interdiscip. Estud. Cid. Campinas, SP V.9, n.3 [17] $\quad$ p.677-711 set./dez. 2017 
SECRETARÍA DE ESTADO DE VIVIENDA (1969). Imágenes de Vivienda. Buenos Aires: Ministerio de Bienestar Social.

SECRETARÍA DE ESTADO DE VIVIENDA (1970). Acción Social en Vivienda 1968-1969. Buenos Aires: Ministerio de Bienestar Social.

SEGRE, Roberto (1977). Las estructuras ambientales en América Latina. México: Siglo XXI.

SCHNEIDER, Nina (2017). Propaganda ditatorial e invasão do cotidiano: a ditadura militar em perspectiva comparada. In: Estudos Ibero-Americanos, 43 (2), 333-345.

SCHTEINGART, Martha y BROIDE, Beatriz (1974). Procesos sociales, política de vivienda y desarrollo metropolitano. El caso de Buenos Aires. In: CASTELLS, Manuel (Comp.), Estructura de clase y política urbana en América Latina. Buenos Aires: Ediciones SIAP, 35-286.

TENTI FANFANI, Emilio (1989). Estado y pobreza: estrategias típicas de intervención. 255 (1). Buenos Aires: Centro Editor de América Latina, Biblioteca Política Argentina.

TORRADO, Susana (1982). El enfoque de las estrategias familiares de vida en América Latina: Orientaciones teórico-metodológicas. Buenos Aires: Centro de Estudios Urbanos y Regionales.

VEKEMANS, Roger y VENEGAS (1996). Ramón. Marginalidad y Promoción Popular. In: Revista Mensaje, n० 149, 218-222.

YUJNOVSKY, Oscar (1984). Las claves políticas del problema habitacional argentino. Buenos Aires: Grupo Editor de América Latina.

ZICCARDI, Alicia (1977). Políticas de vivienda y movimientos urbanos. 1963-1973. In: Documento de Trabajo. Buenos Aires: Centro de Estudios Urbanos y Regionales, Instituto Torcuato Di Tella. 
ZICCARDI, Alicia (1980). Formas organizativas de los asentamientos humanos marginados y política estatal. In: Revista Interamericana de Planificación, 14 (54), 28-40.

ZICCARDI, Alicia (1984). El tercer gobierno peronista y las villas miseria de la ciudad de Buenos Aires (1973-1976). In: Revista Mexicana de Sociología, 46 (4), 145-172. 